\title{
Intense Teaching Schedule in Israeli Teachers
}

\author{
By Yaffa Buskila* \& Tamar Chen-Levi ${ }^{\dagger}$
}

\begin{abstract}
The teaching profession is highly stressful. Stress is a negative phenomenon that develops under conditions of uncontrollable, prolonged and increased pressure. In this study, our goal is (a) to investigate teachers' perception of the sources of stress in school in light of the neoliberal reforms and (b) to compare these sources of stress in primary school, middle school and high school teachers. We hypothesize that the demands and the workload to improve scores in standardized tests, increase the need of teachers to take work home. Therefore, home demands may conflict with school demands. Furthermore, the greatest pressure is on elementary and middle school teachers: Early efforts to improve student achievements in the lower grades would result in betterprepared students in high schools. Data about the sources of stress is based on a previous study of Buskila, Buskila, Giris and Ablin (2019) that investigated the connection between the effects of stress on teachers on somatic syndromes. Three hundred and twenty-one public school teachers working in the Ministry of Education (MOE) in Israel participated in the study. Findings of the mean of the entire samples revealed that the highest level of stress was caused by intense teaching schedule with insufficient breaks. The second cause was related to the composition of the students in the class, and the third was home demands conflicting with school demands. In the middle schools, the highest levels of stress are caused by school principals $(\mathrm{M}=5.98, \mathrm{SD}=3.09)$ and second is in high school $(\mathrm{M}=5.00, \mathrm{SD}=3.33)$. The highest level of stress caused by the superintendent is on primary school teachers $(\mathrm{M}=3.97, \mathrm{SD}=3.33)$ and the second are the middle school teachers $(\mathrm{M}=3.79, \mathrm{SD}=2.95)$. The lowest stress level was in high school $(\mathrm{M}=2.68, \mathrm{SD}=2.83)$. Three significance differences of stress were found among primary, middle, and high schools: The school principal is the highest source of pressure in the middle schools $(\mathrm{P}=.034)$, and the superintendent causes the highest level of stress in primary schools $(\mathrm{P}=.006)$. The third cause was in high school, related to physical school conditions $(\mathrm{p}=.002)$. These results are relevant to teachers, educators, and policy makers involved in planning and managing educational strategies and teachers' schedules. Identifying and preventing the sources of stress can facilitate better teaching conditions, and a more effective and efficient atmosphere in school.
\end{abstract}

Keywords: Stress at school, teachers' stress, causes of stress in school

\section{Introduction}

Recent research has shown that the teaching profession can be very stressful (Montgomery \& Rupp, 2005; Jepson \& Forrest, 2006). Stress is defined as a particular interaction between individuals and their environment, evaluated as being taxing or exceeding their personal resources, and, as a consequence, disrupting daily routines (Lazarus \& Folkman, 1984). Many factors lead to stress in teachers. These factors may vary from time to time, from place to place and from person to person (Griffith, 2004). Stress can result from conflicting incompatible or unclear expectations, from unsatisfied needs, lack of resources and equipment, and difficult work schedules such as working late or overtime (Eres \&

${ }^{*}$ Lecturer, Orot Israel College, Israel.

${ }^{\dagger}$ Lecturer, Bar-Ilan university, Israel. 
Atanasosk, 2011). Stressors might optionally be associated with learning capabilities of students and nonproductive learning environments (Griffith, 2004), organizational climate (Eres \& Atanasosk, 2011) and student behavior (Montgomery \& Rupp, 2005; Verma \& Madhavi, 2017). Stress can be associated with teaching qualifications, parental demands (Kyriacou, 2001) or relationships with any of the stakeholders at schools: peers, principals, superintendents and others (Adi-Rakach \& Gonen, 2013). The school workload and other demands such as the pressure to increase scores on student achievement tests may put extra stress on teachers (Griffith, 2004; Nir, et al., 2016).

Neoliberal reforms taking place all over the world (Carnoy, 1995) and in Israel Ofek Chadash ("The New Horizon") and Oz La Tmura ("The Courage to Change") have made profound changes in the workload of teachers. The goal of these reforms was to raise teachers' professional status (Oplatka, 2017), but in fact, they increased their workload and added to teachers' stress on a daily basis (Schechter, 2015). Teachers in Israel work longer hours than previously, they are expected to increase student achievement on standardized tests, and are required to fill out many administrative forms (Nir, et al., 2016).

Despite the existing research on teachers' stress at work, we have little understanding of how teachers perceive the causes of their stress following the neoliberal reforms. The current study will contribute to our understanding of the effect of these reforms on the lives of teachers. This research is important because, in the recent decades, many countries in the world have legislated reforms that had a major impact on education systems, mainly on the work of teachers and school principals who were expected to implement these changes (Cuban, 1990, p. 22). Moreover, following the reform, teachers are responsible to two different authorities within the educational system: at the national level to the Ministry of Education and at the local level, to the local municipalities, which have the authority to administer the reforms in each city throughout the country. Both the national and the local authorities make demands on schools, which are sometimes in conflict (Nir, et al., 2016). These changes may put pressure on teachers that leads to unresolved disputes among educational communities regarding the value of the neoliberal ideology. Additionally, little information is available on a comparison of the sources of stress at the three school levels.

The study focuses on two questions: What is the source of stress as perceived by teachers in primary, middle, and high schools? Second, what are the differences among primary, middle, and high school teachers regarding the source of their stress?

\section{Literature Review}

Stress has been defined as hardship, adversity, force, tension, anxiety or pressure (Online Etymology Dictionary). Goleman (2006) describes two kinds of stress: Eustress is positive stress that refers to the pressure that mobilizes us to action. The neurochemistry of this type of stress is revealing. When we are positively engaged by a challenge, our brain is soaked in a bath of catecholamines 
and other substances triggered by the adrenal system. These chemicals prime the brain to stay attentive and interested, even fascinated and energized for a sustained effort, stay alert and productive (Goleman, 2006). The other kind of stress occurs when someone is motivated by a fear of failure, or overwhelmed with anxiety, overloaded (Goleman, 2006). We define stress in this study as a force creating mental, physical, or moral pressure.

\section{Unsatisfactory Work and Challenging Conditions}

Teachers represent a specific and unique occupational population. While individuals are typically highly motivated and idealistic (Maaranen, et al., 2016; Haritos, 2004) some report unsatisfactory working conditions: Poor pay, low esteem, and the lack of possibility for professional advancement (Jarvis, 2002). These points might impair teachers' motivation or affect their ability to cope with professional challenges.

Stress can be triggered by various factors that might be associated with students' learning capabilities, behavior (Montgomery \& Rupp, 2005; Verma \& Madhavi, 2017; Ayub, Hussain, \& Ghulamullah, 2018), hyperactivity, aggressive behavior or bulling (Verma \& Madhavi, 2017). Moreover, teachers interact with a wide variety of student populations (Travers \& Cooper, 1996; Montgomery \& Rupp, 2005), and their job consists of many interacting ideas, goals, purposes, and tasks. They have to cope with crises and conflicts with students, parents, peers and each of the school stakeholders (Crick, Barr, Green, \& Pedder, 2017). Stress can also be associated with parental demands as well as those of the school community (Kyriacou, 2001). They also have to maintain good relations with parents, peers, school principals and superintendents (Adi-Rakach \& Gonen, 2013).

Teachers are also required to perform a variety of activities in addition to teaching, and they have little freedom to decide what to teach their students (Ayub, Hussain, \& Ghulamullah, 2018). They are required to maintain a high level of alertness, concentration and physical effort, which all interact in making this lifetime occupation considerably challenging. It is important to note that schools in general, are emotionally charged institutions (James \& Vince, 2001) and despite it most principals give priority to administrative work (Grissom, Loeb, \& Mitani, 2013), rather than the interpersonal aspects of the profession (Harris, 2002). Technology has become an intrinsic part of teaching, which has brought about many new demands in teachers' work (Cox et al., 1988), increasing their stress (Kniveton, 1991).

\section{Neoliberal Reforms, Standardized Tests and Stress}

Neoliberal reforms started during the 1980s, and began as initiatives of the World Bank to help countries in Latin America develop economically and improve people's lives. Later, these reforms affected education in many countries including Israel. They called for competition, equity, and greater financial efficiency. The introduction of more standardized testing was created to increase competition among schools. It was expected that such competition would improve 
the quality of education and raise achievement. Municipalities were required to assume responsibility for education and to encourage private schools and public schools to raise their standards, and to allow students to select the school they wanted to attend. The belief was that such competition would encourage teachers to improve their schools in order not to lose students. Educational planners demanded that limited educational resources be used to achieve greater financial efficiency and higher achievement at a lower cost. The principle of equity demands a quality education with the best teachers as a basic right for all students including the poor, disabled members of minority groups (Carnoy, 1995).

Many countries have enacted neoliberal reforms in the recent decades: United Kingdom, Spain, New-Zealand, French, Chile, Colombia, Australia, USA and Israel. These reforms brought about major changes in education systems, mainly in teachers work, in order to achieve the expected changes (Cuban, 1990, p. 22). In the United Kingdom, they included high-stake tests in 1988 (Hobfoll \& Freedy, 1993). In the United States No Child Left Behind (DiFate, 2008) was legislated in 2002. In Israel, similar reforms were enacted in 2008 and 2010 and, shortly afterwards, standardized tests were initiated resulting in greater pressure on teachers to improve student achievement (Bogler \& Nir, 2014). The reforms in Israel were enacted to enhance teachers' professional development in assessment (Gallagher, et al., 2012) and professional self-esteem (Oplatka, 2017), but they made profound changes on teachers' work (Nir, et al., 2016) adding much stress on a daily basis (Shechter, 2015). The structure of teachers' frame of work was changed, and $30 \%$ more hours of work were added. In primary schools, teachers work 36 hours a week. They teach 31 hours and have five hours for planning lessons, evaluation, checking tests or homework, supervising, meeting with peers, with parents, with students, and with school principals, psychologists etc. In middle school, of the 36-hour teacher post, they teach 27 hours and have nine hours for preparation. In high school, teachers work 40 hours, teach 30 hours, and have ten hours for preparations (MOE, 2013). Teachers are also required to document the number of hours spent with students, what they teach, how many hours they teach, the status of student achievement and more. These demands provoked negative responses and major complaints among teachers, arguing that the reporting interrupts their work (Schecter, 2015).

\section{Effects and Costs of the Stressful Conditions}

Stress is a negative phenomenon that develops under uncontrollable, prolonged and increased pressure. It has physical and mental health consequences and adverse effects at work (Bellingrrath, Weigl, \& Kudielka, 2009). A recent study of 321 teachers in Israel found a high prevalence $(9.3 \%)$ of fibromyalgia syndrome among Israeli teachers, correlated with high levels of stress, compared to population as a whole (2.4\%) (Buskila, et al., 2019). Previous studies focused on specific pain syndromes among teachers, including lower back pain (Bandpei, et al., 2014) and neck pain (Verma \& Madahavi, 2013; Rotermund, at al., 2015). Stress also causes headaches, insomnia, indigestion, and exhaustion (Chan, 1998; Cichon \& Koff, 1980; Dunham 1992; Dworkin, et al., 1990). It can lead to 
depression, anger, anxiety, frustration, fear, self-blame, poor concentration, and memory loss (Blase, 1986; Chan, 1998; Esteve, 1989; Fimian, 1984; Galloway, et al., 1984).

Additional studies demonstrate that occupational stress impairs teaching productivity (Niessen, et al., 2017), damages the quality of teaching, lowers the occupational commitment (Cherniss, 1980), harms effectiveness at work and reduces job satisfaction (Jepson \& Forrest, 2006). It also affects the well-being of individuals and the organization as a whole and, as a result, impairs performance and may lead to absenteeism, reduced staff retention and turnover in schools (Jackson, et al., 1986). Job stress in teachers results in burnout (Jepson \& Forrest, 2006), and leaving the profession mostly due to centralized education systems (Karsenti \& Collin, 2013).

\section{Data on Worldwide Rate of Teacher Attrition}

The problem of teacher attrition is worrisome. In England, the teaching profession is highest on the list of stressful professions. In Switzerland, Scotland, Australia, and New Zealand about $80 \%$ of the teachers suffer from overload at work (Schneider- Levy, 2016). In the United States, Germany, and Israel about $50 \%$ of the teachers leave the profession after five years, and in the United Kingdom, about $44 \%$ of the teachers abandon the profession (Dolton \& klaauw, 1995). In Canada, the estimations vary. In 2004, it was estimated that $30 \%$ of teachers dropped out, and in 2013 it was estimated that $50 \%$ of the teachers left in the first two years mostly because of the excessive workload they brought home (Karasnti \& Collin, 2013). In East Asia, teachers leave the profession because of pressure, burnout, and overwork (Bas, 2011; Montgomery \& Rupp, 2005). In 2017, Professor Oplatka (2017), a senior educator in Israel, warned the policy makers in the Ministry of Education that the reforms may result in good teachers and school principals leaving the educational system because of the stress. On May 2019, the Israeli State Comptroller Report announced a scarcity of 3000 teachers (Detal, 2019).

Leaving the teaching profession and provide replacement staff to schools, and training the new teachers is very expensive (O'Driscoll \& Cooper, 1996). The OECD, the Organization for Economic Co-operational, and Development and the AEE, the Alliance for Excellent Education in the United State estimated that the cost of teacher attrition was almost three billion American dollars in 2004 (OECD Publication, 2005), and possibly now it is higher.

\section{Failed Attempts to Deal with Stress}

The effectiveness of an educational system is usually evaluated through student achievement. The higher the student achievement, the higher the evaluation of the school is. Some studies have suggested looking at the effectiveness of schools by examining organizational adaptations to stress, rather than student achievement (Griffith, 2004). Stress reflects a failure of modern organization in human and financial terms. Levels of stress can be minimized 
when there are adequate resources to meet demands and needs in the workplace (Bala \& Hooda, 2013).

Failure to address the needs of teachers and demanding greater amounts of work, results in higher levels of stress in teachers and subsequently a great many teachers leave the profession. Many of those who remain in the education systems do not meet the needs of the students. Many countries, suffer from a scarcity of teachers and the students pay the highest price for these problems. Countries pay billions of dollars to institute educational reforms, which often result in teachers leaving the profession. In light of the changes that have taken place in recent years throughout the world, we have to understand the sources and impact of stress (Karsenti \& Collin, 2013). Reducing stress may enhance the performance of teachers (Huppert, 2009). In this study, we aim to investigate teachers' perception of the sources of stress in school in light of the neoliberal reforms and to compare the sources of stress among primary, middle, and high school teachers.

\section{Hypothesis}

1. We assume that as the demands and workload on teachers increase in order to improve scores on standardized tests, the need for teachers to work at home will increase. Therefore, home demands conflict with school demands.

2. The greatest pressure exists on teachers in elementary and middle schools: When teachers invest efforts to improve student achievement at the earlier levels, the achievement of students in high school will improve.

\section{Methodology}

\section{Description of the Sample}

Three hundred and twenty-one $(N=321)$ teachers participated in the study, 255 women $(79.4 \%)$ and 66 men $(20.6 \%)$. All the participants are currently working as teachers in the Israeli public-school system in five (out of seven) geographic areas of the MOE: the southern district, the Tel Aviv district, the Jerusalem district, the central district and the northern district. One hundred and seventy $(N=170)$ participants teach in primary school, sixty-six $(N=66)$ teach in middle schools and eighty-five $(N=85)$ teach in high schools (see Table 1$)$. 
Table 1. Participants Matrix

\begin{tabular}{|l|c|c|c|c|c|}
\hline \multicolumn{1}{|l|}{ Participant Matrix } & Total & Percentage & $\begin{array}{c}\text { Primary } \\
\text { School }\end{array}$ & $\begin{array}{c}\text { Middle } \\
\text { School }\end{array}$ & $\begin{array}{c}\text { High } \\
\text { School }\end{array}$ \\
\hline Participants & (N=321) & $\mathbf{1 0 0 \%}$ & $\mathbf{( N = 1 7 0 )}$ & $\mathbf{( N = 6 6 )}$ & (N=85) \\
\hline Gender: & & & & & \\
Men & 66 & $20.6 \%$ & 20 & 20 & 26 \\
Women & 255 & $79.4 \%$ & 150 & 46 & 59 \\
\hline Age: & & & & & \\
$20-29$ & 59 & $100 \%$ & 39 & 17 & 3 \\
$30-39$ & 95 & $100 \%$ & 51 & 22 & 22 \\
$40-49$ & 84 & $100 \%$ & 45 & 17 & 22 \\
50-59 & 55 & $100 \%$ & 30 & 5 & 20 \\
60 and above & 28 & $100 \%$ & 5 & 5 & 18 \\
\hline Academic & 177 & $55.1 \%$ & 102 & 42 & 33 \\
Education: & 132 & $41.1 \%$ & 64 & 23 & 45 \\
BA, B.Ed & 12 & $3.7 \%$ & 4 & 1 & 7 \\
MA, M.Ed & & & & & \\
PhD, Ed.D & & & & & \\
\hline Religion: & 253 & $78.8 \%$ & 127 & 43 & 83 \\
Jewish & 66 & $20.6 \%$ & 42 & 22 & 2 \\
Muslim & 2 & $0.6 \%$ & 1 & 1 & 0 \\
Christian & \multicolumn{5}{|l}{} \\
\hline
\end{tabular}

\section{Methods, Tools and Procedures}

Data about stress was taken from a study by Buskila, Y, et al., (2019), which investigated the connection between teachers' stress at school and its effect on somatic syndromes. In order to measure the stress in that study, we used a questionnaire developed by Foa, Cashman, Jay cox, \& Perry (1997), which was adjusted for use with teachers by Buskila et al., (2019). Six educational experts checked the content validation of the teachers' stress. The questionnaires included basic demographic questions as presented in graph 1 and a series of questions about what they considered as the greatest sources of stress on a wide range Likert scale of 1 to 10 . We asked teachers to rank the sources that cause them the greatest stress: school principals, superintendents, parents, students, peers, overcrowded classrooms, the presence of students with special needs in regular classes, an intense teaching schedule, without breaks, teaching subjects in which they did not have adequate training etc. At the end of the questionnaire, the participants were given an open question to describe their thoughts about sources of stress.

This is a quantitative study. Questionnaires were distributed to teachers by principals, email, or the internet in a Google Doc format. We also sent questionnaires to teachers in graduate programs in educational leadership in three different colleges in Israel. 


\section{Statistical Analysis}

Based on the previous study, we extracted data about the sources and extent of stress and analyzed the data to identify the sources of stress in primary, middle, and high school teachers and compared the sources at the three school levels. We calculated the following data: (a) We checked the stress level of all sources, the means and the standard deviations for each school level separately. The data is presented in descending order for the entire sample and for each school level separately (b) We used an analysis of covariance MANCOVA to compare the sources of stress in teachers by levels of academic education and seniority in teaching, at the three school levels.

\section{Results}

As can be seen in the data presented in graph 1, the highest mean of the sources of stress, with average score of 6.28 out of 10 is an intense teaching schedule with insufficient breaks. The second highest sources with average score of 5.93 is the class composition. The third highest source with average score of 5.91 is the conflict between home demands and work. The fourth source with an average score of 5.44 is related to inadequate classroom physical conditions, and the fifth source, with average score of 5.19, is stress that comes from the school administration, such as principals or vice principals (see Figure 1).

Figure 1. The Mean Sources of Stress for all the Sample, Ranged from the Highest to the Lowest Component $(\mathrm{N}=321)$

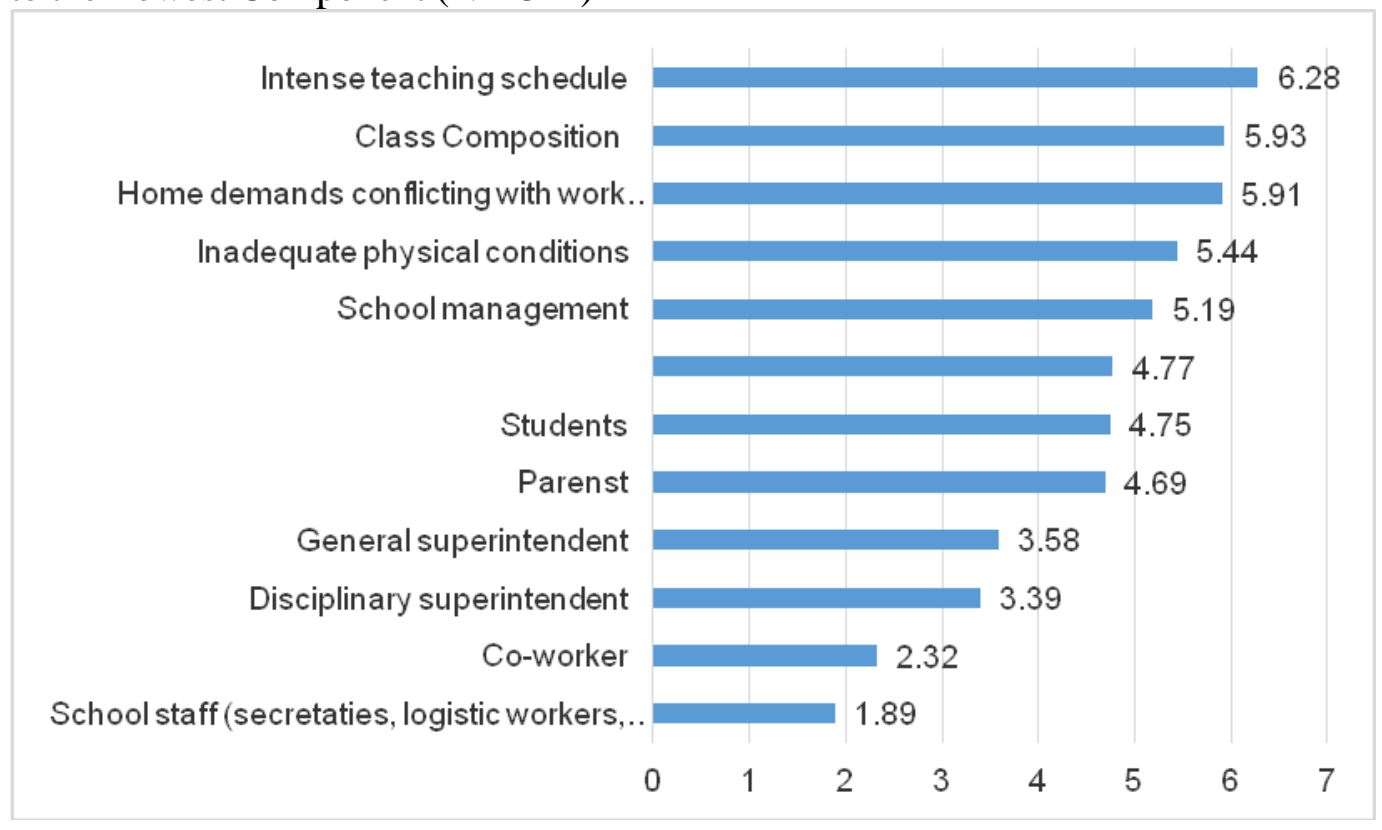




\section{Distinctive Statistics for Stress Elements in Each School Type Separately}

\section{Primary School}

The following table (Table 2) shows descriptive data for teachers in primary school, regarding the sources of work-related stress, ranged from the highest to the lowest.

Table 2. Stress source as Described by Teachers in Primary Schools $(\mathrm{N}=170)$

\begin{tabular}{|l|c|c|c|c|c|}
\hline & $\mathbf{N}$ & Minimum & Maximum & Mean & Std. Dev \\
\hline $\begin{array}{l}\text { 25. Intense teaching schedule (not } \\
\text { enough breaks) }\end{array}$ & 170 & 0 & 10 & 6.10 & 3.335 \\
\hline $\begin{array}{l}\text { 23. Class composition (over-crowding, } \\
\text { special education students etc.) }\end{array}$ & 168 & 0 & 10 & 5.75 & 3.173 \\
\hline $\begin{array}{l}\text { 27. Home demands conflicting with } \\
\text { work demands }\end{array}$ & 166 & 0 & 10 & 5.63 & 3.451 \\
\hline $\begin{array}{l}\text { 19. School administration } \\
\text { 24. Inadequate classroom physical } \\
\text { conditions }\end{array}$ & 169 & 0 & 10 & 4.89 & 3.190 \\
\hline 20. Parents & 169 & 0 & 10 & 4.81 & 3.362 \\
\hline $\begin{array}{l}\text { 26. Demand to teach subjects with } \\
\text { inadequate training }\end{array}$ & 165 & 0 & 10 & 4.59 & 3.210 \\
\hline 22. Students & 168 & 0 & 10 & 4.27 & 3.556 \\
\hline 17. General superintendent & 167 & 0 & 10 & 4.06 & 3.336 \\
\hline 18. Disciplinary superintendent & 163 & 0 & 10 & 3.67 & 3.294 \\
\hline 19. Co-worker & 169 & 0 & 10 & 2.09 & 2.341 \\
\hline $\begin{array}{l}\text { 21. School staff (secretaries, guards, } \\
\text { logistic workers etc.) }\end{array}$ & 166 & 0 & 10 & 1.87 & 2.501 \\
\hline
\end{tabular}

Table 2 demonstrates that the highest source of stress, with an average score of 6.1, is the intense teaching schedule. The second highest source, with an average score of 5.75, is the class composition. The third, with an average score of 5.63 , is the conflict between demands at home and at work. The fourth, with an average score of 4.89 , is the school administration, and the fifth, with an average score of 4.81, is related to inadequate physical class conditions.

\section{Middle School}

The following description shows the descriptive data of teachers in middle schools, regarding the source of stress as they perceive (see Table 3). 
Table 3. Stress Source as Described by Teachers in Middle Schools $(\mathrm{N}=66)$

\begin{tabular}{|l|c|c|c|c|c|}
\hline & $\mathbf{N}$ & Minimum & Maximum & Mean & Std. Deviation \\
\hline $\begin{array}{l}\text { 25. Intense teaching } \\
\text { schedule (not enough } \\
\text { breaks) }\end{array}$ & 66 & 0 & 10 & 6.53 & 3.361 \\
\hline $\begin{array}{l}\text { 23. Class composition } \\
\text { (crowding, special } \\
\text { education students etc.) }\end{array}$ & 65 & 0 & 10 & 6.29 & 3.296 \\
\hline $\begin{array}{l}\text { 27. Home demands } \\
\text { conflicting with work } \\
\text { demands }\end{array}$ & 65 & 0 & 10 & 6.18 & 3.051 \\
\hline 19. School administration & 65 & 0 & 10 & 6.14 & 3.097 \\
\hline $\begin{array}{l}\text { 24. Inadequate classroom } \\
\text { physical condition }\end{array}$ & 65 & 0 & 10 & 6.02 & 3.095 \\
\hline 20. Parents & 63 & 0 & 10 & 5.24 & 4.039 \\
\hline $\begin{array}{l}\text { 26. Demand to teach } \\
\text { subjects with inadequate } \\
\text { training }\end{array}$ & 66 & 0 & 10 & 5.12 & 3.131 \\
\hline 22. Students & 66 & 0 & 10 & 4.65 & 3.256 \\
\hline 17. General superintendent & 63 & 0 & 10 & 3.63 & 2.980 \\
\hline $\begin{array}{l}\text { 18. Disciplinary } \\
\text { superintendent }\end{array}$ & 64 & 0 & 10 & 3.45 & 3.070 \\
\hline 19. Co-worker & 65 & 0 & 10 & 2.83 & 2.929 \\
\hline $\begin{array}{l}\text { 21. School staff (secretaries, } \\
\text { guards, logistic workers } \\
\text { etc.) }\end{array}$ & 61 & 0 & 10 & 2.11 & 3.083 \\
\hline
\end{tabular}

The data in graph 3 demonstrates that the highest source of stress is an intense teaching schedule (not enough breaks) with an average score of 6.53. The second highest is the conflict between demands of home and work with average score of 6.29. The third highest is class composition with an average score of 6.18. The fourth is school administration with an average score of 6.14 and the fifth is related to inadequate classroom physical conditions with an average score of 6.02.

\section{High School}

The following description will demonstrate the descriptive data for high school teacher. See Table 4.

As in the primary and middle schools, the data in table 4 demonstrates that the highest stress source is the intense teaching schedule, with an average score of 6.43. The second highest is the conflict between the demands of home and work, with an average of 6.19. The third highest source is inadequate classroom physical conditions with an average of 6.16. The fourth is class composition with an average of 6.08 and the fifth source of stress is the students, with an average of 5.43. This data partially confirms our first assumption. The second question in our study was to find the differences regarding the source of stress in primary, middle school, and high school teachers. We hypothesized that the highest pressure is on elementary and middle school teachers because the earliest the effort to improve student achievement is in the lower grades and this effort would result in better achievement in high school. 
Table 4. Stress Source as Described by Teachers in High Schools $(\mathrm{N}=85)$

\begin{tabular}{|l|c|c|c|c|c|}
\hline & $\mathbf{N}$ & Minimum & Maximum & Mean & Std. Dev. \\
\hline $\begin{array}{l}\text { 25 Intense teaching schedule (not enough } \\
\text { breaks) }\end{array}$ & 83 & 0 & 10 & 6.43 & 3.437 \\
\hline $\begin{array}{l}\text { 27. Home demands conflicting with work } \\
\text { demands }\end{array}$ & 80 & 0 & 10 & 6.19 & 3.565 \\
\hline 24. Inadequate physical conditions & 82 & 0 & 10 & 6.16 & 3.376 \\
\hline $\begin{array}{l}\text { 23. Class composition (crowding, special } \\
\text { education students etc.) }\end{array}$ & 84 & 0 & 10 & 6.08 & 3.205 \\
\hline 22. Students & 84 & 0 & 10 & 5.43 & 3.402 \\
\hline 26. Da subject with inadequate training. & 73 & 0 & 10 & 5.38 & 4.054 \\
\hline 16. School administration & 84 & 0 & 10 & 5.15 & 3.381 \\
\hline 20. Parents & 84 & 0 & 10 & 4.90 & 3.251 \\
\hline 18. Disciplinary superintendent & 82 & 0 & 10 & 2.80 & 2.683 \\
\hline 17. General superintendent & 82 & 0 & 10 & 2.56 & 2.789 \\
\hline 19. Co-workers & 82 & 0 & 9 & 2.37 & 2.285 \\
\hline $\begin{array}{l}\text { 21. School staff (secretaries, guards, logistic } \\
\text { workers etc.) }\end{array}$ & 81 & 0 & 10 & 1.74 & 2.630 \\
\hline
\end{tabular}

Table 5. Test F, MANCOVA for Calculating the Mean Stress Sources according to three School Levels: Primary, Middle and High School $(\mathrm{N}=321)$

\begin{tabular}{|c|c|c|c|c|c|c|c|c|}
\hline Working data & School level & Mean & $\begin{array}{c}\text { Std. } \\
\text { Deviation }\end{array}$ & $\mathbf{N}$ & $\begin{array}{c}\text { Teaching } \\
\text { level } \\
\mathbf{F}(2,273) \\
\end{array}$ & $\begin{array}{c}\text { Significance } \\
\text { p }\end{array}$ & $\begin{array}{c}\text { Significance } \\
\text { Seniority in } \\
\text { teaching }\end{array}$ & $\begin{array}{c}\text { Significance } \\
\text { Education }\end{array}$ \\
\hline \multirow{3}{*}{$\begin{array}{l}\text { 16. School } \\
\text { administration }\end{array}$} & $\begin{array}{l}1 \text { Primary } \\
\text { school } \\
\text { teacher }\end{array}$ & 4.80 & 3.229 & 152 & & & & \\
\hline & \begin{tabular}{|l}
2 Middle \\
school \\
teachers
\end{tabular} & 5.98 & 3.098 & 58 & $3.418 *$ & .034 & .149 & .574 \\
\hline & \begin{tabular}{|l}
3 High \\
school \\
teachers \\
\end{tabular} & 5.00 & 3.337 & 68 & & & & \\
\hline \multirow{3}{*}{$\begin{array}{l}\text { 17. School } \\
\text { superintendent }\end{array}$} & $\begin{array}{l}1 \text { Primary } \\
\text { school } \\
\text { teacher }\end{array}$ & 3.97 & 3.339 & 152 & & & & \\
\hline & \begin{tabular}{|l}
2 Middle \\
school \\
teachers \\
\end{tabular} & 3.79 & 2.954 & 58 & $5.220 * *$ & .006 & .424 & .245 \\
\hline & \begin{tabular}{|l}
3 High \\
school \\
teachers \\
\end{tabular} & 2.68 & 2.836 & 68 & & & & \\
\hline \multirow{3}{*}{$\begin{array}{l}\text { 18. Disciplinary } \\
\text { superintendent }\end{array}$} & $\begin{array}{l}1 \text { Primary } \\
\text { school } \\
\text { teacher }\end{array}$ & 3.61 & 3.268 & 152 & & & & \\
\hline & \begin{tabular}{|l}
2 Middle \\
school \\
teachers \\
\end{tabular} & 3.50 & 3.102 & 58 & 1.912 & .150 & .644 & .694 \\
\hline & \begin{tabular}{|l}
3 High \\
school \\
teachers \\
\end{tabular} & 2.79 & 2.669 & 68 & & & & \\
\hline \multirow{3}{*}{ 19.Co-workers } & $\begin{array}{l}1 \text { Primary } \\
\text { school } \\
\text { teacher }\end{array}$ & 2.16 & 2.349 & 152 & & & & \\
\hline & \begin{tabular}{|l}
2 Middle \\
school \\
teachers \\
\end{tabular} & 2.67 & 2.886 & 58 & .888 & .413 & .188 & .253 \\
\hline & $\begin{array}{l}3 \text { High } \\
\text { school } \\
\text { teachers }\end{array}$ & 2.32 & 2.269 & 68 & & & & \\
\hline
\end{tabular}




\begin{tabular}{|c|c|c|c|c|c|c|c|c|}
\hline \multirow{3}{*}{ 20. Parents } & $\begin{array}{l}1 \text { Primary } \\
\text { school } \\
\text { teacher }\end{array}$ & 4.57 & 3.172 & 152 & & & & \\
\hline & \begin{tabular}{|l}
2 Middle \\
school \\
teachers \\
\end{tabular} & 4.52 & 3.158 & 58 & .147 & .863 & .424 & $.016 *$ \\
\hline & $\begin{array}{l}3 \text { High } \\
\text { school } \\
\text { teachers }\end{array}$ & 5.19 & 3.297 & 68 & & & & \\
\hline \multirow{3}{*}{$\begin{array}{l}\text { 21. School staff } \\
\text { (secretaries, } \\
\text { logistic workers, } \\
\text { guard etc. }\end{array}$} & $\begin{array}{l}1 \text { Primary } \\
\text { school } \\
\text { teacher }\end{array}$ & 1.89 & 2.487 & 152 & & & & \\
\hline & $\begin{array}{l}2 \text { Middle } \\
\text { school } \\
\text { teachers }\end{array}$ & 2.21 & 3.133 & 58 & .263 & .769 & .258 & .860 \\
\hline & \begin{tabular}{|l}
3 High \\
school \\
teachers \\
\end{tabular} & 1.72 & 2.631 & 68 & & & & \\
\hline \multirow{3}{*}{ 22. Students } & $\begin{array}{l}1 \text { Primary } \\
\text { school } \\
\text { teachers }\end{array}$ & 4.29 & 3.124 & 152 & & & & \\
\hline & $\begin{array}{l}2 \text { Middle } \\
\text { school } \\
\text { teachers }\end{array}$ & 4.93 & 3.150 & 58 & 2.478 & .086 & .315 & .556 \\
\hline & $\begin{array}{l}3 \text { High } \\
\text { school } \\
\text { teachers }\end{array}$ & 5.51 & 3.496 & 68 & & & & \\
\hline \multirow{3}{*}{$\begin{array}{l}\text { 23. Class } \\
\text { composition } \\
\text { (students with } \\
\text { special needs in } \\
\text { regular class } \\
\text { etc.) }\end{array}$} & $\begin{array}{l}1 \text { Primary } \\
\text { school } \\
\text { teacher }\end{array}$ & 5.76 & 3.191 & 152 & & & & \\
\hline & \begin{tabular}{|l}
2 Middle \\
school \\
teachers \\
\end{tabular} & 5.95 & 3.040 & 58 & .140 & .869 & .090 & .160 \\
\hline & $\begin{array}{l}3 \text { High } \\
\text { school } \\
\text { teachers }\end{array}$ & 6.19 & 3.233 & 68 & & & & \\
\hline \multirow{3}{*}{$\begin{array}{l}\text { 24. Classroom } \\
\text { physical } \\
\text { conditions } \\
\text { (room } \\
\text { inadequate, no } \\
\text { A/C, } \\
\text { technological } \\
\text { problems etc. }\end{array}$} & $\begin{array}{l}1 \text { Primary } \\
\text { school } \\
\text { teacher }\end{array}$ & 4.74 & 3.365 & 152 & & & & \\
\hline & \begin{tabular}{|l}
2 Middle \\
school \\
teachers \\
\end{tabular} & 6.19 & 3.198 & 58 & $6.305^{* * *}$ & .002 & .193 & .108 \\
\hline & $\begin{array}{l}3 \text { high } \\
\text { school } \\
\text { teachers }\end{array}$ & 6.44 & 3.343 & 68 & & & & \\
\hline \multirow{3}{*}{$\begin{array}{l}\text { 25. Intense } \\
\text { teaching } \\
\text { schedule (not } \\
\text { enough breaks) }\end{array}$} & $\begin{array}{l}1 \text { Primary } \\
\text { school } \\
\text { teacher }\end{array}$ & 5.96 & 3.357 & 152 & & & & \\
\hline & $\begin{array}{l}2 \text { Middle } \\
\text { school } \\
\text { teachers }\end{array}$ & 6.43 & 3.470 & 58 & .551 & .577 & .066 & .227 \\
\hline & \begin{tabular}{|l}
3 High \\
school \\
teachers \\
\end{tabular} & 6.54 & 3.462 & 68 & & & & \\
\hline \multirow{3}{*}{$\begin{array}{l}\text { 26. Demands to } \\
\text { teach a with } \\
\text { inadequate } \\
\text { training }\end{array}$} & $\begin{array}{l}1 \text { Primary } \\
\text { school } \\
\text { teacher }\end{array}$ & 4.16 & 3.526 & 152 & & & & \\
\hline & \begin{tabular}{|l}
2 Middle \\
school \\
teachers
\end{tabular} & 4.93 & 4.043 & 58 & 1.874 & .155 & .205 & .268 \\
\hline & $\begin{array}{l}3 \text { High } \\
\text { school } \\
\text { teachers }\end{array}$ & 5.46 & 4.046 & 68 & & & & \\
\hline $\begin{array}{l}\text { 27. Home } \\
\text { demands } \\
\text { conflicting with }\end{array}$ & $\begin{array}{l}1 \text { Primary } \\
\text { school } \\
\text { teacher }\end{array}$ & 5.51 & 3.481 & $15 \mathrm{KTJ} 2$ & 2.259 & .106 & .487 & .131 \\
\hline
\end{tabular}




\begin{tabular}{|l|l|l|l|l|l|l|l|l|}
\hline work demands & $\begin{array}{l}2 \text { Midd13 } \\
\text { school } \\
\text { teachers }\end{array}$ & 6.34 & 3.359 & 58 & & & & \\
\hline $\begin{array}{l}3 \text { High } \\
\text { school } \\
\text { teachers }\end{array}$ & 6.51 & 3.462 & 68 & & & & \\
\hline $\mathrm{p}<.05^{*} \mathrm{p}<.01^{* *}$
\end{tabular}

As shown in the MANCOVA matrix, the highest levels of stress caused by school principals is in the middle school $(\mathrm{M}=5.98, \mathrm{SD}=3.09)$. In high schools, this is in second place ( $\mathrm{M}=5.00, \mathrm{SD}=3.33)$. The lowest source of stress caused by school principals is at the primary school $(\mathrm{M}=4.80, \mathrm{SD}=3.22)$. There are significant differences between schools concerning the stress caused by the superintendent. The superintendent caused a greater source of stress in primary school teachers $(\mathrm{M}=3.97, \mathrm{SD}=3.33)$ than in middle school $(\mathrm{M}=3.79, \mathrm{SD}=2.95)$ or high school $(\mathrm{M}=2.68, \mathrm{SD}=2.83)$ teachers. This confirms our second assumption. The highest level of stress among teachers in the primary and middle school is caused by superintendents.

Additionally, we found significant differences among schools regarding the physical conditions in the classrooms. In the primary schools we found $(\mathrm{M}=4.74$, $\mathrm{SD}=3.36)$ the lowest level of stress. In the middle schools we found $(\mathrm{M}=6.19$, $\mathrm{SD}=3.19$ ) and in the high schools we found the highest level of stress regarding physical conditions $(\mathrm{M}=6.44, \mathrm{SD}=3.34)$. Two other components of stress were significant: The first is seniority at work $(\mathrm{P}=.002)$ which means, the higher the seniority, the lower the level of stress in teachers. The second is the academic level source. The higher the academic education of the teacher, the higher the level of stress from parents $(\mathrm{P}=.016)$. In conclusion, we learn from the MANCOVA test that the three differentiating sources among primary, middle, and high schools are the school principal, the school superintendent and the physical conditions in the classroom. Additionally, the higher the seniority at work, the lower the level of stress and the higher the academic education of the teachers in middle schools, the greater the stress from parents.

Table 6. Comparison and Differenced Matrix Among Schools $(\mathrm{N}=321)$

\begin{tabular}{|c|c|c|c|}
\hline The Place & Primary School & Middle School & High School \\
\hline First place & $\begin{array}{l}\text { Intense teaching schedule } \\
\text { (not enough breaks) (6.1) }\end{array}$ & $\begin{array}{c}\text { Intense teaching schedule } \\
\text { (not enough breaks) } \\
(6.53)\end{array}$ & $\begin{array}{l}\text { Intense teaching } \\
\text { schedule (not enough } \\
\text { breaks) }(6.43)\end{array}$ \\
\hline Second place & Class composition (5.63) & $\begin{array}{c}\text { Home demands } \\
\text { conflicting with work } \\
\text { demands }(6.29)\end{array}$ & $\begin{array}{c}\text { Home demands } \\
\text { conflicting with work } \\
\text { demands (6.19) }\end{array}$ \\
\hline Third place & $\begin{array}{c}\text { Home demands } \\
\text { conflicting with work } \\
\text { demands (5.63) }\end{array}$ & Class composition (6.18) & $\begin{array}{c}\text { Inadequate classroom } \\
\text { physical conditions } \\
(6.16) \\
\end{array}$ \\
\hline Fourth place & $\begin{array}{c}\text { School administration } \\
(4.89)\end{array}$ & $\begin{array}{c}\text { Inadequate classroom } \\
\text { physical conditions } \\
(6.14)\end{array}$ & $\begin{array}{c}\text { Class composition } \\
(6.08)\end{array}$ \\
\hline Fifth place & $\begin{array}{c}\text { Inadequate physical class } \\
\text { conditions }(4.81)\end{array}$ & $\begin{array}{c}\text { School administration } \\
(6.29) \text {. }\end{array}$ & Students (5.43) \\
\hline
\end{tabular}


Table 6 compares the differences among the three school levels. The highest sources of stress described by all teachers in the sample $(\mathrm{N}=321)$ is the intense teaching schedule. In second place in middle schools and high schools $(\mathrm{N}=151)$ is the conflict between home and work demands. In primary schools $(\mathrm{N}=170)$ the class composition is in second place as a cause of stress. The conflict between home and work is in third place among primary school teachers. Middle school teachers find the class compositions as a cause of stress and in high school, teachers complain about inadequate physical conditions in the classroom.

\section{Discussion}

The current study aims to investigate teachers' perception of the sources of stress in school in light of the neoliberal reforms and to compare the perception of stress in primary, middle and high school teachers. We demonstrated that an intense teaching schedule with insufficient breaks is the major source of stress in teachers in the entire sample and at each level. This finding, which has not been previously reported, has significant implications for teachers' work. An overly demanding teaching schedule is difficult to handle. Many teachers complain about the lack of breaks to rest, to prepare themselves for the next lesson, to organize their thoughts before their next lesson, to drink, to eat or attend to go to the toilet. One of the teachers wrote: "Every two lessons, we have a break of 15 minute which is not enough." Another teacher commented: "The pressure is due to the long school day and the short breaks of only fifteen minutes that do not leave us time to breathe." One more teacher added, "Students need our attention during breaks, and we do not have enough time to catch our breath before the next lesson, to go to the restroom or to drink or eat before the next lesson

The teaching schedule hours was expanded: Teachers in primary schools work 7.2 hours a day and teach 6.2 hours a day. They have only one hour a day for preparations, and other assignments such as meetings with parents, co-workers, students, checking exams and homework, preparing lessons, writing programs and coordinating ceremonies, special events, trips, parties etc. Middle school teachers work 7.2 hours each day. They teach 5.4 hours, which means that they have 1.8 hours a day for preparations and assignments. In high schools, teachers work 8 hours per day and teach 6 hours a day, leaving them two hours a day for preparations and many assignments. The non-teaching hours are insufficient for the work involved. This also explains the results in Figure 1: The mean sources of stress for all the samples in third place was the conflict between the home and demands and school demands. These schedules show an over utilization of human resources of teachers as said by teachers in the study of Karsenti \& Collin (2013, p. 145): "Too much work has to be done... and too heavy workload."

Stress can be viewed as a failure of the modern organization in both human and financial terms and can be solved by money (Griffith, 2004). In many countries, billions of dollars are invested every year for reforms, which have not been successful in raising the scores on standardized tests (Barber \& Murshed, 2007). The general cost of education in Israel rose tremendously from 2000 to 
2012, and today is above those of the OECD (Blasé \& Kogan, 2016). There is no reason to believe that there is a lack of resources, but the list of priorities for spending the money should be revised. Teachers work long hours and overtime, have insufficient breaks and work many hours at home adding to their stress (Eres \& Atanasosk, 2011) The stress of teachers in Israel is a result of a gap between reality and expectations. Teachers continue to work at home at the expense of time with their families. The demands of the job and their home are often in conflict. Revising the priorities according to the classes and teachers' needs might be helpful. Stress can impair the health of teachers, and harm their self-esteem (Schechter, 2015) making it difficult to achieve the expected performance and leading to ineffective education (Wangui, et al., 2016). These may also explain the low scores in the standardized tests in many countries including Israel despite the investment of efforts to improve these scores.

The three distinct sources among primary, middle, and high schools are the school principal, the superintendent and physical conditions in the classroom. The greatest source of stress in middle school cause by the school principal $(\mathrm{P}=.034)$. The superintendent is a greater cause of stress, in primary schools $(\mathrm{P}=.006)$ and the greatest source of stress on high school is the physical conditions of the school $(\mathrm{P}=.002)$. Apparently, school principals and superintendents are different stressors in primary and middle schools. However, they both share the goal of improving students' performance on national and international standardized tests (Nir et al, 2016) as directed by the Ministry of Education. Our assumption that they would be a greater source of stress in elementary and middle schools than in high school was confirmed.

Two other components of stress were found to be significant. First, at the higher levels of seniority there was less stress $(\mathrm{p}=.002)$ at all the school levels. Experienced teachers are better able to cope with a wide range of problems. However, the second result, that teachers with more advanced degrees experience greater the stress from parents $(\mathrm{P}=.016)$, is surprising. Learning is very important and contributes to growth and development of teachers, raising their self-esteem, self-confidence and much more. Learning knowledge and skills of teachers are the most important determinants of student success (Darling-Hammond \& Youngs, 2002). Learning covers all aspects of education, embracing everything in it (Dhaliwal, 2015). What many studies conclude is that the single most important factor in student achievements is high quality teaching (Haycock, 1998) that meet the challenges of the 21 st century, ongoing efforts are needed to improve the education of teachers (Hellenberg, 2010; Nir et al., 2016). There is increased pressure in the United States to provide highly qualified teachers (Cavalluzzo, 2004). As a result, the educational community is focused on the importance of teacher quality and the types of continuing professional development available to teachers to improve the quality of their instruction (Hellenberg, 2010). We believe that the finding that the higher the academic education of teachers the greater the stress they experience from parents is related to the low professional image of teachers in many places in the world (Barer \& Murshad, 2007) including Israel, and to the lack of respect for teachers (Karsenti \& Collin, 2013) in Israel and elsewhere (Raychel, 2012). There are many reasons for this low image such as low 
salaries, demanding work, pressure to satisfy parents and the challenge of relating to parents (Karsenti \& Collin, 2013). Teachers work in a turbulent and competitive environment and often face a public satisfied with the educational system (Schecter \& Tschanned-Moran, 2006).

\section{Theoretical Contribution, Limitations, further Research and Meaning of the Study}

Although considerable attention has focused on stress in teachers resulting from the changes that have occurred in the educational systems around the world, there have been few empirical studies examining stress from the perspectives of teachers. For this reason, studies such as ours are important. Schools still have no autonomy; the public schooling system in 2015 in Israel is more a declarative autonomy (Nir, et al., 2016). Local municipalities have authority on the schools in given areas (Addi -Raccah, 2006). Other organizations have also attempted to cooperate with schools (Berkovich \& Folder, 2012) and to participate in the reshaping of the educational system. These initiatives have a direct impact on schools and on teachers and reveal complex and contradictory pressures (Sagie, Yemini, \& Bauer, 2016). Recognizing and understanding the causes for changes and stressors are important in order to know how to handle them and how to prevent them.

There are a few limitations in our research. This study was conducted in Israel and the results are influenced by the local culture and society, local management and organizational culture (Luthans \& Avolio, 2003). Similar research in other cultures would contribute to our understanding of stress both in Israel and in other countries. We believe that it will help to construct new knowledge. Our results are relevant to teachers, educators and policy makers involved in planning and managing educational strategies. Identifying and preventing the sources of stress can facilitate better teaching conditions, and a more productive educational atmosphere in schools.

\section{References}

Adi-Raccah, A. (2006). School leaders' collaboration with external school agencies: a comparison between regular and unsterilized schools, International Journal of Knowledge, Culture and Change Management, 6(2), 27 - 38.

Ayub, A., Hussain, M. A., \& Ghulamullah, N. (2018). Causes and impact of work stress on teacher's performance in urban primary schools. Journal of Research in Social Sciences, 6(1), 81-100.

Bala, N., \& Hooda, N. (2013). Extent of occupation stress among primary and secondary school teachers in relation to sex (male and female) in Sirsa. International Journal of Education \& Management Studies, 3(2), 268 - 271.

Barber, M., \& Mourshed, M. (2007). How the world's most improved school systems keep getting better. McKinsey \& Company. 
Bas, G. (2011). Teacher student control ideology and burnout: Their correlation. Australian. Journal of Teacher Education, 36(4), 84 - 94.

Bellingrath, S., Weigl, T., \& Kudielka, B. M. (2009). Chronic work stress and exhaustion in associated with higher allostatic load in female school teachers. Stress: The International Journal of the Biology of Stress, 12(1), 37 - 48.

Berkovithch, I., \& Folder, V.J. (2012). Third sector involvement in public education: The Israeli case. Journal of Educational Administration, 50(2), 173 - 187.

Bandpei, M. A. M., Ehsani, F., Behtash, H., \& Ghanipour, M. (2014). Occupational low back pain in primary and high school teachers: prevalence and associated factors. Journal of manipulative and physiological therapeutics, 37(9), 702-708.

Bogler, R., \& Nir. A. (2014). The contribution of perceived fit between job demands and abilities to teachers' commitment and job satisfaction. Educational Management Administration and Leadership, 43(4), 541 - 560.

Buskila, Y., Buskila, D., Jacob, G., \& Ablin, J. N. (2019). High prevalence of fibromyalgia among Israeli school teachers. Clin Exp Rheumatol, 37(116), S21-S26.

Cavalluzzo, L. C. (2004). Is National Board Certification an Effective Signal of Teacher Quality?. CNA Corporation.

Cichon, D. J., \& Koff, R. H. (1980). Stress and teaching. NASSP Bulletin, 64(434), 91104.

Cox, T., Boot, N., Cox, S., \& Harrison, S. (1988). Stress in schools: An organizational perspective. Work \& Stress, 2(4), 353-362.

Crick, R. D., Barr, S., Green, H., \& Pedder, D. (2017). Evaluating the wider outcomes of schools: Complex systems modelling for leadership decisioning. Educational Management Administration \& Leadership, 45(4), 719-743.

Cuban, L. (1990). Reforming again, again, and again. Educational researcher, 19(1), 3-13.

Darling-Hammond, L., \& Youngs, P. (2002). Defining highly qualified teachers: What does scientifically based research tell us? Education Researcher, 31(9), 13-25.

Detal Lior, (May 6, 2019). Auditor's Report: how to raise a lost generation: Shortage of 3000 teachers while those teaching are unqualified. Retrieved from https://bit.ly/3cEZbXL. [Hebrew].

Dhaliwal, M. K. (2015). Teachers becoming lifelong learners. The Business \& Management Review, 5(4), 259 - 264.

DiFate, T. L. (2008). Stress factors of elementary and middle school teachers associated with high stakes testing as required by No Child Left Behind. Dissertation. University of Bridgeport.

Dolton, P. \& Van der Klaauw, W. (1995). Leaving teaching in the UK: A duration analysis. Economic Journal, 105(429), 431- 444.

Dunham, J. (1992). Stress in teaching. New York: Routledge.

Dworkin, A.G., Haney, C.A., Dworkin, R.J. \& Telschow, R.L. (1990). Stress and illness behavior among urban public-school teachers. Educational Administration Quarterly, 26, 60-72.

Eres, F., \& Atanasoska, T. (2011). Occupational stress of teachers: A comparative study between Turkey and Macedonia. International Journal of Humanities and Social Science, 1(7), 59-65.

Esteve, J. (1989). Teacher burnout and teacher stress. In M. Cole and S. Walker (Eds.), Teaching and stress (pp. 4-25) Philadelphia, PA: Open University Press.

Fimian, M.J. (1984). The development of an instrument to measure occupational stress in teachers: The teacher stress inventory. Journal of Occupational Psychology, 57, 277293. 
Foa, E. B., Cashman, L. Jaycox., L., \& Perry. K. (1997). The validation of a self-report measure of posttraumatic stress disorder: The posttraumatic diagnostic scale. Psychological Assessment, 9, 445 - 451 .

Galloway, D., Panckhurst, F., Boswell, K., Boswell, C., \& Green, K. (1984). Mental health, absences from work, stress and satisfaction in a sample of New Zealand primary school teachers. Australian and New Zealand Journal of Psychiatry, 18, 359363.

Gallagher, Carmel, Hipkins, Rosemary, \& Zohar, Anat (2012). Positioning thinking within national curriculum and assessment systems: Perspectives from Israel, New Zealand and Northern Ireland. Thinking skills and Creativity, 7(2), 134-143.

Goleman, D. (2006). Working with emotional intelligence. New York: Bantam books.

Grissom, J. A., Loeb, S., \& Mitani, H. (2013) Principal time management skills: explaining patterns in principals time use and effectiveness. Stanford University: Center for Education Policy.

Grifffith, J. (2004). Ineffective schools as organizational reactions to stress. Social Psychology of Education, 7, 254 - 287.

Haritos, C. (2004). Understanding teaching through the minds of teacher candidates: a curious blend of realism and idealism. Teaching and Teacher Education. 20(6), 637654.

Harris, L. C. (2002). The emotional labor of barristers: An exploration of emotional labor by status professionals. Journal of Management Studies, 39(4) 553 - 584.

Haycock, K. (1998). Good teaching matters a lot. Santa Cruz, CA: The Center for the Future of Teaching and Learning.

Hellenberg, J. (2010). Wyoming teacher perceptions of teacher quality: effects of National Board Certification and teacher education level. University of Wyoming.

Hobfoll, S.E., \& Freedy, J. (1993). Conservation of resources. A general stress theory applied to burnout. In Schaufeli, W.B., Maslach. C. \& Marek, T. (eds), Professional Burnout. Recent Developments in Theory and Research, (pp. 115 - 133). Taylor and Francis, Washington, DC.

Huppert, F. A. (2009). Psychological well-being: evidence regarding its cause and consequences. Applied Psychology: Health and well-Being. 1(2), 137 - 164.

Jackson, S. E., Schwab, R. L., \& Schuler R.S. (1986). Toward and understanding the burnout phenomenon. Journal of Applied Psychology, 71, 639 - 640.

James, C., \& Vince, R. (2001). Developing the leadership capability of headteachers, Educational Management, Administration \& Leadership, 29(3), 307 - 317.

Jarvis, M. (2002). Teacher stress: A critical review of recent finding and suggestions for future research. Stress News the UK Journal of the International Stress Management Association. 14(1), 12 - 16.

Jepson, E., \& Forrest, S. (2006). Individual contributory factors in teachers stress: The role of achievement striving and occupational commitment. British Journal of Educational Psychological, 76, 183 - 197.

Karsenti, T., \& Collin, S. (2013). Why are new teachers leaving the profession? Results of Canada-Wide survey. Education, 3(3), 142 - 149.

Kniveton, B.H. (1991). An investigation of factors contributing to teachers' job satisfaction. School Psychology International, 12, 361 - 371.

Kyriacou, c. (2001). Teacher stress: Directions for future research. Educational Review, 53(1) $27-35$.

Lazarus, R. S. \& Folkman, S. (1984). Stress, appraisal and coping. New York: McGrawHill Book Company. 
Luthans, F., \& Avolio, B. J. (2003). Authentic leadership development. In K.S. Cameron, J.E. Dutton, \& R.E. Quinn (eds.), Positive Organizational Scholarship, (pp. 241 258). San Franciscan: Berrett-Koehler.

Maaranen, K., Pitkäniemi, H., Stenberg, K., Karlsson, L. (2016). An idealistic view of teaching: teacher students' personal practical theories. Journal of Education for Teaching, 42(1), 80-92.

Ministry of Education. Teachers' working hours in high school. Retrieved from https://bit.ly/3fPZ3Xp. [Hebrew].

Ministry of Education. Teachers' working hours in primary school. Retrieved from https://bit.ly/2T1sJa6. [Hebrew].

Ministry of Education. Teachers' working hours in secondary school. Retrieved from https://bit.ly/2yR2NXP. [Hebrew].

Montgomery, C., \& Rupp, A. A. (2005). A Meta-analysis for exploring the diverse causes and effects of stress in teachers, Canadian Journal of Education, 29(3) 458 - 486.

Niessen, C., Mader, I., Stride, C., \& Jimmieson, N.L. (2017). Thriving when exhausted: The role of perceived transformational leadership. Journal of Vocational Behavior, $103,41-51$.

Nir, A., Ben-David, A., Bogler, R., Inbar, D., \& Zohar, A. (2016). School autonomy and $21^{\text {st }}$ century skills in the Israeli educational system: Discrepancies between the declarative and operational levees, International Journal of Educational Management, 30(7), 1231 - 1246.

O'Driscoll, M. P., \& Cooper, C. L. (1996). Source and management of excessive job stress and burnout. In P. Warr (ed.). Psychology at Work,(pp. 182 - 223). London: Penguin Books.

Oplatka, Y. (2017). A new glance on Ofek Chadash, Hed Hachinuch. Periodical Magazine of the Israeli teacher's union, 35(5), 98. [Hebrew].

Organization for Economic Co-Operation and Development (2005). Teachers matter: Attracting developing and retaining effective teachers. Paris, France: OECD Publication.

Raychel, N. (2012). The ideal image of the teacher and conditions for developing it from the perspective of articles in the journals of professional teacher organizations: 19802000. In Klavir, Rama and Kozminski, Lea (eds.), The Construction of personal identity: Process of Teacher Education and Professional Development. Tel Aviv: Mofet Institute. [Hebrew]

Rottermund, J., Knapik, A., Saulicz, E., Mysliwiec, A., Saulicz, M., Reigiel, KA, \& Linek, P. (2015). Back and neck pain among school teachers in Poland and its correlations with physical activity. Med $\mathrm{Pr}, 66(6), 771$ - 778.

Sagie, N., Yemini, M., \& Bauer, U. (2016). School-NGO interaction: Case studies of Israel and Germany. International Journal of Sociology and Social Policy, 36(7/8), 469-490.

Shechter, C. (2015). Let Us lead! School principals in the front line of the reforms. Tel Aviv: Ramot Publications, Tel Aviv University. [Hebrew].

Schechter, C., \& Tschanned-Moran, M. (2006). Teachers' sense of collective efficacy: an international view. The International Journal of Educational Management; Bradford, 20(6), 480 - 489.

Schneider-Levy, L. (2016). Impact of inquiry-based stress reduction (IBSR) on teacher burnout and mental well-being. (unpublished $\mathrm{PhD}$ dissertation), Tel Aviv University. [Hebrew].

Travers, C.J., \& Copper, C.L. (1996). Teachers under pressure: Stress in the teaching profession. Routledge. London. 
Verma, R. Madhavi, K. (2017). The effect of postural education on decreasing the severity of neck pain in female school teachers: A Prospective Cohort Study. International Journal of Therapies and Rehabilitation Research, 6(1), 24.

Wangui, M. F., Omboi, K., \& Irabo, M. (2016). Effects of work-related stress on teachers performance in public secondary schools in Kikuyu Sub County, Kenya. International Journal of Science and Research, 5(5), 1645-1652. 